\title{
Influence of enzyme preparations on the growth and development of Ross-308 cross meat chickens
}

\author{
Dilbar Vakhidova ${ }^{1, *}$, Akmalkhuja Fayzildinov ${ }^{1}$, and Khusniddin Donaev ${ }^{1}$ \\ ${ }^{1}$ Tashkent State Agrarian University, University str., 2, Tashkent province, Uzbekistan, 100140
}

\begin{abstract}
The studies were carried out in 2017-2018 in the poultry farm of OJSC JV firm "Virtech-Agro" (joint American-Russian-Uzbek enterprise), which is located in the Zangiata district of the Tashkent region, $25 \mathrm{~km}$ from the city of Tashkent, Uzbekistan. As a result, the characteristics of broiler chickens of the Ross-308 cross, technical conditions of use and characteristics of flavomycin, its effect on the growth of chickens and on the quality of feed during long-term storage, the effect on the digestive process and pathogenic microflora in Uzbekistan were studied. The results obtained show that the use of these components shortens the broiler rearing period from 38 to 42 days, increases weight gain, improves the meat quality of chickens, reduces feed costs and, at the same time, reduces labor costs for workers.
\end{abstract}

\section{Introduction}

Poultry farming is one of the largest livestock industries in our Republic. In Uzbekistan, it is developing through the specialization and intensification of poultry farms and farms $[1$, 4-8]. The increase in the production of poultry meat is based on a significant increase in the productivity of poultry with a simultaneous increase in its livestock with a high payment for feed products and an increase in productivity $[2,3]$. A significant and steady growth in the production of poultry products became possible due to the creation of a solid forage base, and above all, an increase in the production of grain (corn, barley, fodder wheat, legumes) used for poultry feed [6].

In intensive poultry farming, more and more attention is paid to providing poultry with vitamin and mineral feed. The organization of poultry factories and farms specialized in the production of meat; the use of highly productive poultry required the development and application of new methods and norms of feeding, corresponding to the conditions of intensive poultry farming [6-9].

The rationed feeding system provides, first of all, to meet the needs of the bird in raw protein and energy metabolism. Rationing for metabolic energy and nutrient complex should correspond to the physiological needs of a highly productive bird and the preservation of its health [8].

\footnotetext{
* Corresponding author: vdilbarhon@yandex.ru
} 
The physiologically determined basis is balanced feeding on a complex of nutrient, biologically active, mineral substances, micro- and macro-elements, based on their action in the exchange processes on the body, with the most effective conversion of feed into poultry meat [6, 10-14]. Against this background, the use of biologically active additives and enzymes in the composition of feed is relevant. Based on the above, we focused on the use of a drug from the hostazim group - Flavomycin [11]. Our studies allow us to determine the effect of the enzyme on the digestibility of feed and an increase in nutritional values, the effect on weight gain in broilers.

\section{Materials and methods}

Proceeding from the fact that in the literature available to us, no sources of research conducted with the enzyme flavomycin on chickens of the Ross-308 cross in our region have been found, we have established, in a short time, saving working time and feed, methods of improving the quality of poultry meat, increasing the meat yield, taking into account the hot climate of Uzbekistan [15-19].

Significant progress has been achieved in the study of the mineral nutrition of poultry and in the specification of the norms of macro- and - microelements. Mineral substances are very important in the life of a bird and make up 3-4\% of the live weight of a bird. The lack of one or several minerals reduces the productivity and fertility of the bird, sometimes leads to death [18].

Based on this, we are assigned tasks:

1. the search for non-medical components, in particular, to introduce into the diet of poultry an enzyme preparation from the hostazim group - flafomycin and to study the effectiveness of its action as well as the possibilities for wider use in practice;

2. in the feeding system, develop scientifically grounded standards for the needs of young animals in enzyme preparations, namely, to improve the quality of meat and increase productivity;

3. to develop norms and combinations of feeds based on the mass of dry feed, to determine the possible amount of feed (in grams) and enzymes (in grams) that a bird receives per day, to establish the content of nutrients in it, while planning in such a way as to provide the bird all nutrients and vitamins;

4. to combine a ration for feeding broiler chickens from 1 to 42 days of age, based on the planned production, as well as to be as cheap as possible.

As a result of our research, we have studied the following issues:

- technical conditions for the use of an enzyme from the hostazim group - Flafomycin;

- the effect of an enzyme from the hostazim group - Flavomycin on the growth of broiler chickens of the Ross-308 cross;

- efficient use of enzymes in order to save other components, especially during the growth of chickens;

- the approximate yield of broiler chickens' droppings per day at different age periods (1-42 days), as well as the content of nutrient residues in them;

- indicative feeding rates in high temperature conditions (in summer months);

- norms for the need of broiler chickens in compound feed with enzyme additives per head per day;

- the content of vitamin supplements in the feed of broiler chickens of the Ross-308 cross;

- the content of trace elements in the feed of broiler chickens of the Ross-308 cross.

Broilers of the Ross-308 cross have fast growth, excellent preservation and growth of live weight, as well as the lowest feed conversion. Aviagen, a world-leading group of 
geneticists and breeders, has perfected the use of the latest breeding technologies to ensure even annual improvement in critical traits such as welfare, feed conversion and meat yield, which means the Ross 308 broiler performs better than when either.

Ross-308 represents the best combination of broiler reproductive performance and processing performance, resulting in a higher economic return. From the simple calculation below, it is obvious that Ross-308 provides customers with a higher income per herd.

Continuous improvement in important characteristics such as total chick numbers and safety leads to the Ross-308 continuing to set the standard for the entire poultry industry. With higher hatching egg numbers, higher hatchability and higher chick numbers, combined with the world's best retention, Ross-308 consistently outperforms competitors in breeding

\section{Results and discussion}

\subsection{Technical conditions for the use of the enzyme Flavomycin}

Almost all feeds to one degree or another contain various substances those are difficult to digest - non-starchy polysaccharides that are not broken down in the digestive tract. Difficult to digest and absorb nutrients, these compounds form a viscous mass in which the diffusion of nutrients is very difficult. Entering the lower parts of the intestine, this mass serves as a nutrient substrate for microorganisms living there, including pathogenic ones. The use of specific enzymatic complexes for each feed component that breaks down nonstarchy polysaccharides can significantly increase the digestibility of protein and amino acids of carbohydrates, significantly increases. This leads to an improvement in feed conversion, an increase in safety and live weight, which in general leads to a decrease in costs per unit of production.

The use of feed antibiotics in animal feeding is an important reserve for the rational use of feed in the production of animal products. The use of reasonable norms for their introduction into the composition of mixed fodders can significantly improve productivity indicators and reduce the cost of production.

The introduction of feed antibiotics into animal diets improves metabolism, allows for more efficient use of feed, increases the body's resistance, reduces morbidity and reduces livestock waste. Kormogrizin, bacillichin, biovit, etc. are known from domestic preparations, and flavomycin, zincbycitracin, virginiamycin, etc. are known from foreign preparations. Moreover, a number of authors talk about the periodic replacement of feed antibiotics in feed, so as not to addictive animals to drugs.

The firm "Hoechst AG" (Germany) offers the preparation flavomycin specially developed for animal husbandry. This feed antibiotic is a prophylactic enzymatic rather than hormonal or chemical stimulant of productivity. Its active ingredient is Flavophospholipol. It acts against all gram-positive bacteria, leaving alive lactobacilli and bifidobacteria useful for animals and supplied with food. Externally, Flavomycin is a light brown or beige powder in micro granular form. It should be mixed with compound feed in a stepwise way: preferably in a three-step way or through a vitamin-mineral complex. The product is compatible with all feed additives. When Flavomycin was created, the condition was set that it did not remain in the tissues of the animal, and after acting in the small intestine, it was completely excreted with droppings. Today the drug is approved for feeding almost all animal species. Histological studies carried out by Hoechst Ag have shown that flavomycin in the form of an intact molecule is excreted from the body in the droppings. No metabolites are formed in the gastrointestinal tract. After adding the drug to the feed in an amount of $550 \mathrm{mg} / \mathrm{kg}$ for weeks, months, years, neither in chickens, nor in 
rats, nor in pigs and calves did not appear in the blood, muscles, liver, kidneys, skin, adipose tissue, eggs or bones no residues. An important quality of the drug is its effect on reducing the daily water intake of poultry. The result is an improvement in the microclimate, drier droppings (by 5-19\%), and better quality bedding material [17]. The use of antibiotics for the prevention and treatment of diseases with prolonged use of drugs often leads to a decrease in their effectiveness and to the formation of resistance of pathogens to the drug. This phenomenon is called infectious resistance. In this case, the hereditary information responsible for resistance, the so-called P-plasmids, are transmitted from resistant microorganisms to as yet nonresistant, as a result of which they acquire the same resistance. Flavomycin actively prevents the transmission of P-plasmids. This effect of flavomycin is most significant, as it becomes possible to reduce resistant E. colli and salmonella. The drug reduces the existing resistance of gram-negative microorganisms against drugs (tetracycline, ampicillin, streptomycin) and can prevent the formation of such resistance. When using flavomycin, bacterial infections that threaten livestock can be treated much easier, faster, and cheaper. The effectiveness of therapeutic interventions is improving.

Compared with bacitracin, flavomycin is 10,000 times more active in suppressing the formation of the cell wall of an unwanted microorganism. Due to the high bacterial activity, the drug is dosed in small quantities [18].

Flavomycin, getting into the gastrointestinal tract of a bird with feed, suppresses the development of unwanted microflora, which increases resistance to stress and infections, reduces the formation of toxins, improves the absorption of nutrients, vitamins, microelements, increases the safety, productivity of poultry, and reduces feed costs for products.

\subsection{Influence of the Flavomycin enzyme on the growth of Ross-308 broilers}

Different doses of Flavomycin were introduced into the feed ration of broiler chickens in order to determine the optimal one. In the experimental and control groups, the chickens were given the same diet, with the only difference that the experimental ones were supplemented with Flavomycin. We started with a dose of $37.5 \mathrm{~g}$ per 1 ton of feed.

First experiment. In the control group there were 25 chickens (Table 1), in 3 experimental groups, 25 chickens each (the amount of flavomycin was $37.5 \mathrm{~g}$ per ton of feed).

Table 1. Productivity indicators when using Flavomycin $(37.5 \mathrm{~g} / \mathrm{t})$ in the poultry farm "Vertex-Agro".

\begin{tabular}{|c|c|c|}
\hline Indicators & Control group & $\begin{array}{c}\text { Experimental group } \\
\text { (flavomycin 37.5 g/t) }\end{array}$ \\
\hline Initial stock of broilers, heads & 25 & 25 \\
\hline Broilers raised, heads & 23 & 24 \\
\hline Death,\% & 8 & 48 \\
\hline Growing period, days & 48 & 156 \\
\hline Live weight of 1 head at slaughter, g & 1,567 & 29.61 \\
\hline Average daily gain, g & 28.0 & 3,307 \\
\hline Feed consumption per broiler, g & 3,303 & 2.64 \\
\hline Feed consumption per broiler, $g$ & 2.8 & \\
\hline
\end{tabular}


Second experiment. The number of heads in the control and experimental groups remained the same (25 each), the rearing period (46 days) and the amount of flavomycin $(40 \mathrm{~g} / \mathrm{t})$ were changed. The results are displayed in the following Table 2.

Table 2. Productivity indicators when using Flavomycin ( $40 \mathrm{~g} / \mathrm{t})$ in the poultry farm "Vertex-Agro".

\begin{tabular}{|c|c|c|}
\hline Indicators & Control group & $\begin{array}{c}\text { Experimental group } \\
\text { (flavomycin 40 g/t) }\end{array}$ \\
\hline Initial stock of broilers, heads & 25 & 25 \\
\hline Safety.\% & 92 & 96 \\
\hline Growing period, days & 46 & 1,690 \\
\hline Live weight of 1 head at slaughter, g & 1,580 & 32.6 \\
\hline Average daily gain, g & 31.1 & 2.64 \\
\hline Feed consumption per 1 kg gain, $\mathrm{kg}$ & 2.80 & 46 \\
\hline
\end{tabular}

Third experiment. The number of chickens in the control and experimental groups remained the same ( 25 each), the rearing period ( 42 days) and the amount of flavomycin $(60 \mathrm{~g} / \mathrm{t})$ were changed. The results are displayed in the following Table 3.

Table 3. Productivity indicators when using Flavomycin $(60 \mathrm{~g} / \mathrm{t})$ in the poultry farm "Vertex-Agro".

\begin{tabular}{|c|c|c|}
\hline Indicators & Control group & $\begin{array}{c}\text { Experimental group } \\
\text { (flavomycin 40 g/t) }\end{array}$ \\
\hline Initial stock of broilers, heads & 25 & 25 \\
\hline Broilers raised, heads & 24 & 25 \\
\hline Death, $\%$ & 4 & - \\
\hline Growing period, days & 42 & 42 \\
\hline Live weight of 1 head at slaughter, g & 1,648 & 32,780 \\
\hline Average daily gain, g & 31 & 3,860 \\
\hline Feed consumption per broiler, g & 3,920 & \\
\hline
\end{tabular}

\section{Conclusions}

Positive results have been obtained and the economic efficiency of using the drug has been obtained. The use of Flavomycin gave an increase in the safety of livestock, an increase in growth, a decrease in feed costs, an increase in the category of meat. If we consider that the main thing when growing broilers is gaining live weight up to 6-8 weeks of life (the period of laying the reproductive organs), then in the experimental group the standard for live weight was reached by 6 weeks of age ( 42 days), and in the control group there is a lag of 132 days. From the data of the conducted experiments, the following conclusions can be drawn:

In broiler chickens, the slaughter weight increases by $90-132 \mathrm{~g}$.

1. Saving from 60 to $160 \mathrm{~g}$ of feed per broiler produced; 
2. Reduction of bird mortality by $3-5 \%$;

3. Higher efficiency in the use of production capacities by reducing the feeding period;

4. More efficient use of feed leads to less water consumption by broilers and, as a result, to drier rooms, an improved microclimate in the workshop, while reducing the risk of infections and the cost of additional ventilation;

5. Reduced exposure to stress, improved protection against diseases and, as a result, more even development of broilers;

6. Savings in feed: when using Flavomycin: when using only $60 \mathrm{~g}$ of Flavomycin per 1 ton of feed, when feeding 1000 broilers, this leads to an increase in slaughter weight by 100 $\mathrm{kg}$ and a saving of $300 \mathrm{~kg}$ of feed.

\section{References}

1. N. Teshaev, B. Mamadaliyev, A. Ibragimov, S. Khasanov, InterCarto. InterGIS, 26(3), 324-333 (2020)

2. D. Azimov, Zooveterinary, 6, 16 (2009)

3. A. Jumanov, S. Khasanov, A. Tabayev, G. Goziev, U. Uzbekov, E. Malikov, IOP Conf. Ser.: Earth Environ. Sci., 614(1), 012150 (2020)

4. S. Azimov, I. Khushvakov, Zooveterinary, 2, 26 (2000)

5. S. Azimov, I. Khushvakov, Zooveterinary, 2, 32 (2009)

6. A. Abdusattarov, Journal of Veterinary Medicine, 2, 18 (2008)

7. R. Kulmatov, A. Taylakov, S. Khasanov, Environ. Sci. Pollut. Res., 28(10), 1224512255 (2021)

8. S. Isaev, S. Khasanov, Y. Ashirov, T. Karabaeva, A. Gofirov, E3S Web Conf., 244, 02012 (2021)

9. N. A. Bystrova, Russian National Congress "Man and Medicine", 231 (2009)

10. S. Isaev, S. Khasanov, Y. Ashirov, A. Gofirov, T. Karabaeva, E3S Web Conf., 244, 02047 (2021)

11. R. Davlatov, KH. Salimov, Zooveterinary, 2, 26 (2006)

12. I. Egorov, V. Manukyan, Zooveterinary, 8, 22 (2009)

13. R. A. Kulmatov, S. A. Adilov, S. Khasanov, IOP Conf. Ser.: Earth Environ. Sci., 614(1), 012149 (2020)

14. I. A. Egorov, Compound feeding, 4, 32 (2008)

15. S. K. Isaev, R. U. Rakhmonov, S. S. Tadjiev, G. I. Goziev, S. Z. Khasanov, IOP Conf. Ser.: Earth Environ. Sci., 614(1), 012147 (2020)

16. I. Aslanov, S. Khasanov, Y. Khudaybergenov, M. Groll, Ch. Opp, F. Li, E. Ramirez Del-Valle, E3S Web Conf., 227, 02005 (2021)

17. Z. Mamatkulov, E. Safarov, R. Oymatov, I. Abdurahmanov, M. Rajapbaev, E3S Web Conf., 227, 03001 (2021)

18. Y. Salimov, A. Nuraliyev, Zooveterinary, 5, 21 (2009)

19. I. A. Smirnov, A. Mikhalev, Zooveterinary, 6, 14 (2009) 